\title{
Factors Influencing Consumers' Buying Decision in Indian Trade Show: Evidence from Mahalaxmi Saras Exhibition, Mumbai
}

\author{
Madhumita Patil ${ }^{1}$ Jayashree Bhakay $^{2}$ Barsharani Maharana $^{1 *}$ \\ 1. Chetana's Institute of Management and Research, Survey No. 341, Government Colony, Bandra East, \\ Mumbai 400051, India \\ 2. Chetana's RK Institute of Management and Research, Survey No. 341, Government Colony, Bandra East, \\ Mumbai 400051, India \\ * E-mail of the corresponding author: barsha.iips@gmail.com
}

\begin{abstract}
This study endeavors to explore the factors that influence buying decision of consumers in the trade show Mahalaxmi Saras organised in Mumbai. To fulfil the objective the data is collected from the consumers who visited the trade show in 2020. The total sample size consists of 249 respondents. Univariate analysis is used to study the economic and demographic background of the consumers, bivariate analysis is adopted to assess customers' perception towards price of the products available by their income level. Further, factor analysis is employed to identify the important factors influencing consumers' buying decision. The findings reveal that more than half of the consumers eagerly wait for the exhibition and fifty-five percent consumers agree that they visit more than once during the time span of the exhibition. However, consumers' satisfaction level towards price of the product decreases with decrease in level of income. Result from factor analysis indicates that Product's variety, artistic value, quality, exclusive nature, cultural importance and encouragement of rural entrepreneurs and artisans are the important components that influence consumers' buying decision. Hence, Government and participating SHGs should take care of fixing the price of the products in order to attract more consumers. Also, rural entrepreneurs and artisans should be encouraged to participate in the exhibition to avail variety of products.

Keywords: Consumers, Buying decision, factors, Trade show, India

DOI: $10.7176 / \mathrm{JMCR} / 79-05$

Publication date:June $30^{\text {th }} 2021$

\section{Introduction}

Trade shows are defined as events which bring together in a single location a group of suppliers, distributors, and related services that set up physical exhibits of their products from a given industry or discipline (Herbig, O'Hara, and Palumbo, 1997). Trade show organisers aim to create highly effective shows that benefit both exhibitors and visitors. From an organiser and exhibitor perspective it is important to understand what visitors believe constitutes an effective trade show. Most empirical work that exists examines effectiveness from an organisational or business buyer perspective and appears to overlook how perceptions of trade show effectiveness are developed by consumers (Hansen, 1996). Trade show organisers aim to create highly effective shows that benefit both exhibitors and visitors. From an organiser and exhibitor perspective then, it is important to understand what consumers believe constitutes an effective trade show. Trade shows represent an important avenue for manufacturers and retailers to engage with a market. Consumers are likely to have different motivations for attending trade shows and exhibit different forms of behaviour than industrial buyers and may therefore assess effectiveness differently. The absence of suitable measures to operationalise trade shows effectiveness from the consumers' perspective thus represents a gap in the literature that needs to be addressed.
\end{abstract}

\section{Review of literature}

Although trade shows are frequently conceptualised as promotional tools that involve both direct selling and advertising (Blythe, 1999, Gopalakrishna and Lilien, 1995, Hansen, 2004, Smith, Gopalakrishna, and Smith, 2004), alternative views have been proposed. For example, Munuera and Ruiz (1999) argues that trade shows are more like a service involving a series of activities that must be perfectly coordinated. Trade shows are multifaceted business tools and the manner in which their effectiveness is measured may be contextually dependent on the perspective of the evaluator. The broad definition of effectiveness adopted in this study is that proposed by Kottmann (2002), who suggests it is the degree to which a predefined objective matches an achieved objective independent of the input. If a predefined objective has been achieved it is effective and this constitutes a success. Objectives reflect the results that trade show attendees (both visitors and exhibitors) expect to achieve 
through trade show participation (Browning and Adams, 1988). Research indicates that exhibitors seldom set specific objectives prior to attending trade shows (Blythe, 1997, Gopalakrishna and Lilien, 1995). From a trade show organiser's perspective, show success depends not only on the exhibitors but also to a large extent on the visitors (Munuera and Ruiz, 1999), so it is likely to be important that exhibitors and organisers understand what it is that consumers feel makes the show effective.

Consumer behaviour is a continuous consumption process related to pre-purchase, purchase and post purchase issues. This refers to the physical action of consumers that can be directly observed and measured by others. According to Solomon and Rabolt (2004), consumer behaviour is the study of the processes involved when individuals or groups, select, purchase, use or dispose of products, services, ideas or experiences to satisfy needs and desires. According to Kardes (2002), consumer behaviour is the study of consumer responses to products, services, and the marketing of products and services. One of the biggest cultural amalgamations in the city, the Mahalaxmi Saras Exhibition has been started at the MMRDA Grounds in Bandra Kurla Complex, Mumbai. Expect tons and tons of stalls including handicraft products, food products, jewellery, handloom, home essentials and utility, textiles and lot more. This initiative was started by the Maharashtra Government in 2003 to provide a market place to rural entrepreneurs and artisans. Claimed to be one of the biggest rural exhibitions in India. From the above review of literature, it is noted that sporadic attempts have been made to study the influence of factors on consumers' buying decision in India, particularly in trade shows. As there is dearth of studies on exploring the factors affecting consumers' buying decision, the present study is an attempt to fill this research gap. Therefore, the main objectives of the study are 1) to identify the factors that influence the buying decision of consumers in the trade show Mahalaxmi Saras and 2) To study the consumers' perception regarding the availability, quality and hygiene of food products.

\section{Mahalaxmi Saras}

An initiative of the Government of Maharashtra to provide a marketing platform to rural entrepreneurs and artisans, Mahalaxmi SARAS is an annual exhibition-cum-sale of handicrafts, handlooms and food products. In its 16th year now, Mahalaxmi SARAS 2020 held from 17th Jan to 29 January, 2020 at MMRDA Ground, Ground No:- 1,4,5 \& 6. BKC Bandra (E), Mumbai, Maharashtra. One of the biggest rural exhibitions held in the country, Mahalaxmi SARAS has introduced nearly 5000 Self Help Groups to the urban consumers in the last decade. In addition to Self Help Groups (SHGs) from Maharashtra, SHGs from various states of India have participated in this annual extravaganza. This rural exhibition is a melting pot of different cultures and cuisines. There were many stalls from different parts of the country like Uttar Pradesh, Shimla, Kashmir, Punjab, Orissa, Assam, Rajasthan, Bihar, and Tamil Nadu. Various products like ready to eat, ready to cook, direct consumables, art, handicrafts, handlooms, home decoration etc. were available in the exhibition. The speciality of the food courts of the exhibition was visitors were given a chance to try several Indian food varieties.

\section{Data \& Methods}

\subsection{Data}

Data for the present study is collected through primary survey. A survey type questionnaire was developed by following the Likert scale technique for scale construction of the items in questionnaire. The first portion of questionnaire was about demographics like gender, age, occupation and income level. The second section consists of the question on factors influencing consumer buying behaviour, the third section comprises of the question related to food availability, safety and hygiene, the fourth section covers the questions on arrangements in the exhibition. The responses are coded as strongly agree to strongly disagree. The data has been collected using purposive sampling. The responses have been collected from 249 customers who have visited Mahalaxmi Saras Exhibition.

\subsection{Methods}

Firstly, univariate analysis is used to show the economic and demographic background of study population, to study the frequency of visit by the customers and to know whether customers eagerly wait for the exhibition. Secondly, a bivariate analysis is adopted to assess customers' perception towards price of the products available at Mahalaxmi Saras by income level. Further, factor analysis is employed to identify the important factors influencing customers' buying decision and reliability test is used to measure the standard of food available in the exhibition. 


\section{Result}

The economic and demographic background of the study population is shown in Table 1. The table portrays that out of the total customers who have visited the trade show, Mahalaxmi Saras, almost three-fifth (58.6\%) of them are females and two-fifth (39.3\%) is males. Most of the customers (89.1\%) belong to age group 18-57 and only one-tenth is of age 58 years and above. As per the occupational status, majority of the customers are service holders/professionals (46.8\%) and homemakers (28.7\%), however, $16 \%$ of the customers are students and $8.4 \%$ are business holders. It is observed that only $15.6 \%$ of the customers who visit Mahalaxmi Saras belong to low income group, $21.9 \%$ belong to high income group and more than three-fifth $(62.5 \%)$ of the customers belong to middle income group. It is evident from Table 1 that most of the customers are females, adults, service holders/professionals and belong to middle income group.

Table 1: Distribution of customers' demographic and economic characteristics, Mahalaxmi Saras, Mumbai, 2020

\begin{tabular}{lc}
\hline Gender & 39.3 \\
Male & 58.6 \\
Female & \\
Age & 45.6 \\
$18-37$ & 43.5 \\
$38-57$ & 10.9 \\
$58+$ & \\
hanOccupation & 16.0 \\
Students & 46.8 \\
Services/professional & 28.7 \\
Homemaker & 8.4 \\
Business & \\
Income & 15.6 \\
Low & 62.5 \\
Middle & 21.9 \\
High & 249 \\
\hline Total(n) & \\
\hline
\end{tabular}

It is evident from Figure 1 that more than half $(60.9 \%)$ of the customers who visit Mahalaxmi Saras strongly agree/agree that they eagerly wait for the exhibition. Fifty-five percent customers strongly agree/agree that they visit more than once during the time span of the exhibition (Figure 2). During the survey customers' perception towards price of the products are taken care of. Findings indicate $45.6 \%$ customers strongly agree/agree that in the exhibition products are fairly priced (Figure 3). Among the customers belong to low income group 34.3\% strongly agree/agree that in the exhibition products are fairly priced. However, $42.9 \%$ in middle income group and $61.2 \%$ in high income group think that products are fairly priced. It is observed from Figure 3 that customers' satisfaction toward price of the product increases with increase in level of income.

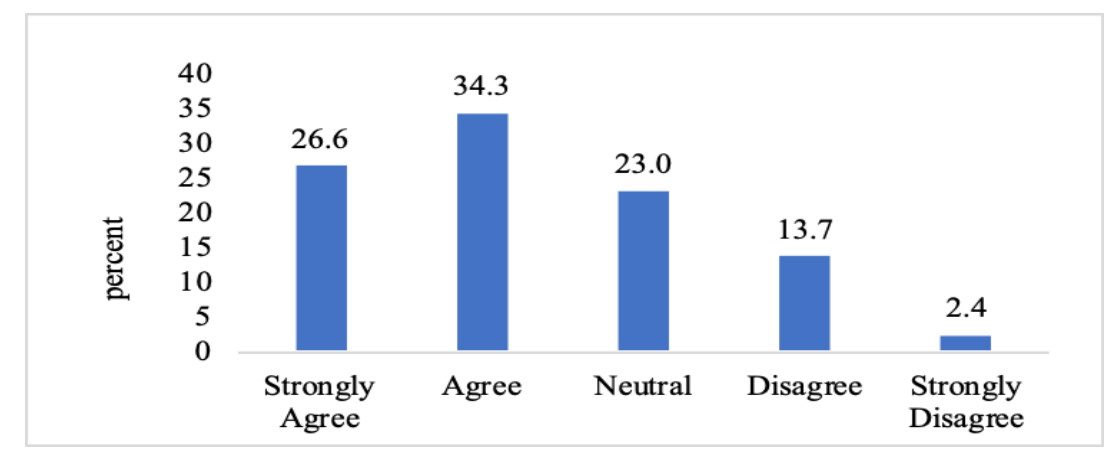

Figure 1: Distribution of customers who eagerly wait for Mahalaxmi Saras exhibition every year 


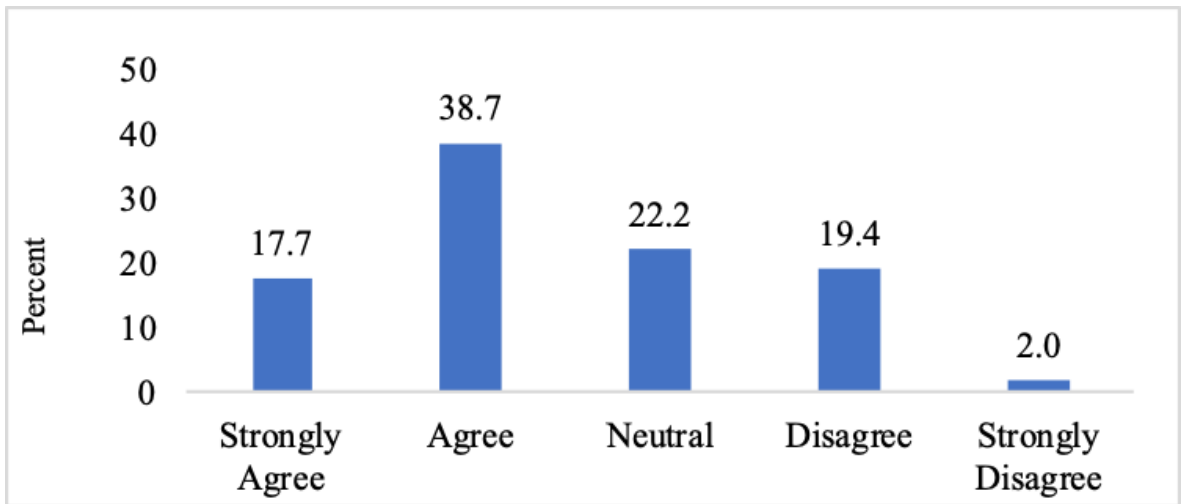

Figure 2: Distribution of customers who visit saras more than once during the time span of the exhibition

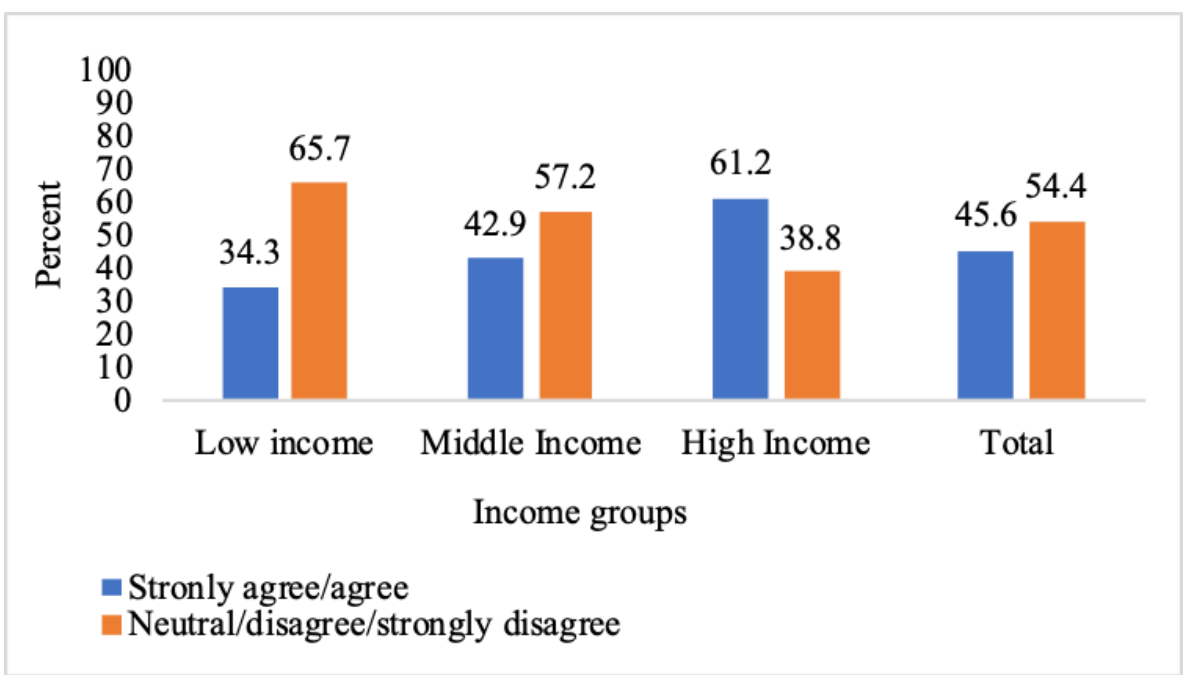

Figure 3: Customer perception towards price of the products available at Mahalaxmi Saras by income level

The factors affecting buying decision of customers are shown in Table 2. During the survey customers were asked the reasons for buying products from Mahalaxmi Saras exhibition. The factors affecting buying decision of customers are shown in Table 2. Genuineness is one of the important factors influencing the buying decision, as $26.1 \%$ customers strongly agree and $52.6 \%$ agree that they buy products from the exhibition because they are more genuine than those produced in factories. Most of the customers buy to encourage rural entrepreneurs and artisans (38.8\% strongly agree and $40.7 \%$ agree). Availability of variety of products is an imperative factor influencing buying decision. Around $29 \%$ customers strongly agree and $42 \%$ agree that they buy from the exhibition because a variety of products are availed from different parts of the country under one roof. Customers are attracted towards the artistic value of the product as $24.6 \%$ customers strongly agree and $43.6 \%$ agree that they buy products for their artistic value. Likewise, exclusive nature, cultural importance and quality of the products are the influential factors affecting consumers; buying decision. 
Table 2: Factors influencing customers' buying decision in Mahalaxmi Saras, Mumbai, 2020

\begin{tabular}{|c|c|c|c|c|c|}
\hline Factors & $\begin{array}{l}\text { Strongly } \\
\text { Agree }\end{array}$ & Agree & Neutral & Disagree & $\begin{array}{l}\text { Strongly } \\
\text { Disagree }\end{array}$ \\
\hline $\begin{array}{l}\text { Products are more genuine than those produced } \\
\text { in factories }\end{array}$ & 26.1 & 52.6 & 19.7 & 0.8 & 0.8 \\
\hline $\begin{array}{l}\text { To encourage the rural entrepreneurs and } \\
\text { artisans }\end{array}$ & 38.3 & 40.7 & 17.7 & 2.0 & 1.2 \\
\hline $\begin{array}{l}\text { There are variety of products from different } \\
\text { parts of the country under one roof }\end{array}$ & 28.7 & 42.1 & 23.9 & 4.1 & 1.2 \\
\hline Products have artistic value & 24.6 & 43.6 & 28.6 & 2.0 & 1.2 \\
\hline Products are exclusive in nature & 20.6 & 53.2 & 23.8 & 2.0 & 0.4 \\
\hline Cultural importance & 26.1 & 45.0 & 26.5 & 2.4 & \\
\hline Good quality & 25.7 & 47.0 & 22.5 & 3.6 & 1.2 \\
\hline
\end{tabular}

\subsection{Results from factor analysis}

The Kaiser-Meyer-Olkin Measure of Sampling Adequacy is a statistic that indicates the proportion of variance in the variables that might be caused by underlying factors. The results indicate that a factor analysis can be applied to the data as the value of Kaiser-Meyer-Olkin Measure of Sampling Adequacy (0.749) is high and Bartlett's test of sphericity is significant (Table 3.1).

Table 3.1: KMO and Bartlett's Test

\begin{tabular}{|c|c|c|}
\hline $\begin{array}{l}\text { Kaiser-Meyer-Olkin Measur } \\
\text { Bartlett's Test of Sphericity }\end{array}$ & $\begin{array}{l}\text { of Sampling Adequacy. } \\
\text { Approx. Chi-Square } \\
\text { df } \\
\text { Sig. }\end{array}$ & $\begin{array}{r}.749 \\
275.458 \\
21 \\
.000\end{array}$ \\
\hline
\end{tabular}

Initial eigenvalues are the variances of the factors and each variable has a variance, and the total variance is equal to the number of variables used in the analysis, in this case, 7 (Table 3.2). The total column contains the eigenvalues. The first factor always accounts for the most variance (and hence have the highest eigenvalue), and the next factor accounts for as much of the left over variance as it can, and so on. Hence, each successive factor accounts for less and less variance. The variance column contains the percent of total variance accounted for by each factor. The cumulative column contains the cumulative percentage of variance accounted for by the current and all preceding factors.

Table 3.2: Total Variance Explained

\begin{tabular}{|c|c|c|c|c|c|c|c|c|c|}
\hline \multirow[b]{2}{*}{ Component } & \multicolumn{3}{|c|}{ Initial Eigenvalues } & \multicolumn{3}{|c|}{$\begin{array}{c}\text { Extraction Sums of Squared } \\
\text { Loadings }\end{array}$} & \multicolumn{3}{|c|}{$\begin{array}{c}\text { Rotation Sums of Squared } \\
\text { Loadings }\end{array}$} \\
\hline & Total & $\begin{array}{c}\% \text { of } \\
\text { Variance }\end{array}$ & $\begin{array}{c}\text { Cumulative } \\
\%\end{array}$ & Total & $\begin{array}{c}\% \text { of } \\
\text { Variance }\end{array}$ & $\begin{array}{c}\text { Cumulative } \\
\%\end{array}$ & Total & $\begin{array}{c}\% \text { of } \\
\text { Variance }\end{array}$ & $\begin{array}{c}\text { Cumulative } \\
\%\end{array}$ \\
\hline 1 & 2.611 & 37.306 & 37.306 & 2.611 & 37.306 & 37.306 & 1.582 & 22.600 & 22.600 \\
\hline 2 & .984 & 14.058 & 51.363 & .984 & 14.058 & 51.363 & 1.513 & 21.609 & 44.209 \\
\hline 3 & .893 & 12.763 & 64.126 & .893 & 12.763 & 64.126 & 1.39 & 19.917 & 64.126 \\
\hline 4 & .796 & 11.375 & 75.501 & & & & & & \\
\hline 5 & .696 & 9.947 & 85.448 & & & & & & \\
\hline 6 & .611 & 8.724 & 94.172 & & & & & & \\
\hline 7 & .408 & 5.828 & 100.000 & & & & & & \\
\hline
\end{tabular}

Extraction Method: Principal Component Analysis.

There are three factors resulting from the analysis explaining a total of $64.126 \%$ of the variation in the entire data set (Table 3.2). The percentage of variation explained by the first, second and third factors are 22.600, 21.609 and 19.917 percent respectively. The rotated component matrix is used using 0.50 as a cut-off point for factor loading for naming the factors (Table 3.3). In this way three factors are found. Factor 1 comprises variables (I get variety of products from different parts of the country under one roof) and (I buy the products because of their artistic value). Factor 2 comprises variables (I buy to encourage the rural entrepreneurs and artisans) and (I buy products from saras because I think they are of good quality). Factor 3 comprises variables (I believe that some 
of the products are exclusive in nature) and (I like buying products from saras for their cultural importance). It is observed that out of the seven components, six are most important to influence customers' buying decision.

Table 3.3: Rotated Component Matrix

\begin{tabular}{|c|c|c|c|}
\hline & \multicolumn{3}{|c|}{ Component } \\
\hline & 1 & 2 & 3 \\
\hline $\begin{array}{l}\text { I buy products from saras because } i \text { think they are more } \\
\text { genuine than those produced in factories }\end{array}$ & .316 & .201 & .496 \\
\hline I buy to encourage the rural entrepreneurs and artisans & .310 & .671 & .140 \\
\hline $\begin{array}{l}\text { I get variety of products from different parts of the country } \\
\text { under one roof }\end{array}$ & .758 & .411 & .073 \\
\hline I buy the products because of their artistic value & .821 & .046 & .236 \\
\hline I believe that some of the products are exclusive in nature & .320 & -.123 & .769 \\
\hline $\begin{array}{l}\text { I like buying products from saras for their cultural } \\
\text { importance }\end{array}$ & -.166 & .433 & .686 \\
\hline $\begin{array}{l}\text { I buy products from saras because } i \text { think they are of good } \\
\text { quality }\end{array}$ & .084 & .805 & .075 \\
\hline
\end{tabular}

\subsection{Perception of customers about food standard}

Standard of food available in the exhibition is measured using three questions asked to the customers regarding availability, quality and hygiene of food items in the exhibition. In order to understand whether the questions (variables) reliably measure the food standard, a Cronbach's alpha is run as it is the most common measure of internal consistency. Findings from reliability test reveals that all the three variables are highly correlated with each other (Table 4). The value of Cronbach's alpha is 0.7403 , therefore all the questions are reliable to measure the standard of the food.

Table 4: Reliability test to measure food standard

\begin{tabular}{lcccccc}
\hline \multicolumn{1}{c}{ Item } & Obs & Sign & $\begin{array}{c}\text { Item-test } \\
\text { correlation }\end{array}$ & $\begin{array}{c}\text { Item-rest } \\
\text { correlation }\end{array}$ & $\begin{array}{c}\text { Average } \\
\text { interitem } \\
\text { covariance }\end{array}$ & $\begin{array}{c}\text { Cronbach's } \\
\text { alpha }\end{array}$ \\
\hline $\begin{array}{l}\text { I love the food items } \\
\text { available at the food stalls }\end{array}$ & 245 & + & 0.8402 & 0.6034 & 0.368199 & 0.6036 \\
$\begin{array}{l}\text { I believe that the food items } \\
\text { are prepared with proper } \\
\text { hygiene at the food stalls }\end{array}$ & 249 & + & 0.8735 & 0.659 & 0.296588 & 0.526 \\
$\begin{array}{l}\text { Food products are free from } \\
\text { adulteration and preservation }\end{array}$ & 251 & + & 0.7089 & 0.435 & 0.64184 & 0.7838 \\
\hline \begin{tabular}{l} 
Test scale \\
\hline
\end{tabular} & & & & 0.434898 & 0.7403 \\
\hline
\end{tabular}

\section{Conclusion}

It is evident from the study that most of the customers are females, adults, service holders/professionals and belong to middle income group. More than half of the customers eagerly wait for the exhibition and fifty-five percent customers agree that they visit Mahalaxmi Saras more than once during the time span of the exhibition. Findings also indicate that slightly less than half of the customers agree that in the exhibition products are fairly priced and customers' satisfaction level towards price of the product decreases with decrease in level of income. Result from factor analysis reveals that there are six important factors which influence customers' buying decision. Customers buy from the exhibition to encourage the rural entrepreneurs and artisans, because there are variety of products from different parts of the country available under one roof, products have artistic value, because of exclusive in nature of the product, cultural importance, and good quality of the product. Further, results from reliability test shows that customers are quite satisfied with the standard of food available in Mahalaxmi Saras. Hence, Government and participating SHGs need to reach a consensus about fixing the price of the products in order to attract more customers. Nevertheless, Government should encourage more rural 
entrepreneurs and artisans to participate in the exhibition to avail variety of products for the customers, and SHGs should be conveyed to maintain the quality of the products and food.

\section{References}

Blythe, J. (1997). Does size matter? Objectives and measures at UK trade exhibitions. Journal of Marketing Communications. 3(1), 51-59.

Blythe, J. (1999). Learning by doing: frequency of exhibiting at UK trade exhibitions. Journal of Marketing Communications. 5(4), 207-221.

Browning, J. M., \& Adams, R. J. (1988). Trade shows: an effective promotional tool for the small industrial business. Journal of Small Business Management. 26(4), 31-36.

Gopalakrishna, S., \& Lilien, G. L. (1995). A three-stage model of industrial trade show performance. Marketing Science. 14(1), 22-42.

Hansen, K. (1996). The dual motives of participants at international trade shows. International Marketing Review. 13(2), 39-53.

Hansen, K. (2004). Measuring performance at trade shows: scale development and validation. Journal of Business Research. 57(1), 1-13.

Herbig, P. A., O'Hara, B. S., \& Palumbo, F. (1997). Differences between trade show exhibitors and nonexhibitors. Journal of Business \& Industrial Marketing. 12(6), 368-382.

Kardes, F. R. (2002). Consumer Behavior and Managerial Decision Making. Second edition. Pearson Education.

Kottmann, K. (2002). Methodenlexikon der FHT Esslingen, Fach Hochschule für Technik,

Munuera, J. L., \& Ruiz, S. (1999). Trade fairs as services: a look at visitors' objectives in spain. Journal of Business Research. Vol. 44(1), 17-24.

Smith, T. M., Gopalakrishna, S., \& Smith, P. M. (2004). The complementary effect of trade shows on personal selling. International Journal of Research in Marketing. 21(1), 61-76.

Solomon, M.R, \& Rabolt, Nancy J.(2006).Consumer Behaviour in Fashion, Pearson Education. 